\title{
Research Article \\ Selective Synthesis of Manganese/Silicon Complexes in Supercritical Water
}

\author{
Jiancheng Wang, ${ }^{1}$ Zhaoliang Peng, ${ }^{1}$ Bing Wang, ${ }^{1}$ Lina Han, ${ }^{1,2}$ Liping Chang, \\ Weiren Bao, ${ }^{1}$ and Gang Feng ${ }^{3}$ \\ ${ }^{1}$ State Key Laboratory Breeding Base of Coal Science and Technology Co-founded by Shanxi Province and \\ the Ministry of Science and Technology, Taiyuan University of Technology, Taiyuan 030024, China \\ ${ }^{2}$ College of Materials Science and Engineering, Taiyuan University of Technology, Taiyuan 030024, China \\ ${ }^{3}$ Shanghai Research Institute of Petrochemical Technology, SINOPEC, Shanghai 201208, China
}

Correspondence should be addressed to Weiren Bao; baoweiren@tyut.edu.cn and Gang Feng; fengg.sshy@sinopec.com

Received 9 February 2014; Accepted 14 March 2014; Published 4 May 2014

Academic Editor: Wen Zeng

Copyright (c) 2014 Jiancheng Wang et al. This is an open access article distributed under the Creative Commons Attribution License, which permits unrestricted use, distribution, and reproduction in any medium, provided the original work is properly cited.

\begin{abstract}
A series of manganese salts $\left(\mathrm{Mn}\left(\mathrm{NO}_{3}\right)_{2}, \mathrm{MnCl}_{2}, \mathrm{MnSO}_{4}\right.$, and $\left.\mathrm{Mn}(\mathrm{Ac})_{2}\right)$ and silicon materials (silica sand, silica sol, and tetraethyl orthosilicate) were used to synthesize $\mathrm{Mn} / \mathrm{Si}$ complexes in supercritical water using a tube reactor. X-ray diffraction (XRD), Xray photoelectron spectrometer (XPS), transmission electron microscopy (TEM), and scanning electron microscopy (SEM) were employed to characterize the structure and morphology of the solid products. It was found that $\mathrm{MnO}_{2}, \mathrm{Mn}_{2} \mathrm{O}_{3}$, and $\mathrm{Mn}_{2} \mathrm{SiO}_{4}$ could be obtained in supercritical water at $673 \mathrm{~K}$ in 5 minutes. The roles of both anions of manganese salts and silicon species in the formation of manganese silicon complexes were discussed. The inorganic manganese salt with the oxyacid radical could be easily decomposed to produce $\mathrm{MnO}_{2} / \mathrm{SiO}_{2}$ and $\mathrm{Mn}_{2} \mathrm{O}_{3} / \mathrm{SiO}_{2}$. It is interesting to found that $\mathrm{Mn}(\mathrm{Ac})_{2}$ can react with various types of silicon to produce $\mathrm{Mn}_{2} \mathrm{SiO}_{4}$. The hydroxyl groups of the $\mathrm{SiO}_{2}$ surface from different silicon sources enhance the reactivity of $\mathrm{SiO}_{2}$.
\end{abstract}

\section{Introduction}

Recently, the growth of manganese silicate $\left(\mathrm{Mn}_{2} \mathrm{SiO}_{4}\right)$ and manganese dioxide $\left(\mathrm{MnO}_{2}\right)$ barrier layers on the $\mathrm{SiO}_{2}$ surface through the deposition of metal $\mathrm{Mn}$ and $\mathrm{Mn} / \mathrm{Cu}$ alloys after high temperature annealing has attracted considerable investigations $[1,2]$. These self-forming diffusion barrier layers can effectively prevent the diffusion of $\mathrm{Cu}, \mathrm{O}$, and $\mathrm{H}_{2} \mathrm{O}$ and have been proposed as a scalable alternative to $\mathrm{Ta} / \mathrm{TaN}$ barrier layers in the future $[3,4]$. However, the synthesis method employed was limited to high temperature annealing and the unreacted metallic Mn still remained after the formation of barrier layer, which would diffuse to the surface of the deposited $\mathrm{Cu}$ interconnect. Moreover, the uncertainty of chemical composition of products undermined the potential application of this barrier layer $[5,6]$. Furthermore, the lowvalence manganese oxides, supported and unsupported, have attracted great attentions as catalytically active components in a variety of catalytic reactions, for example, the selective catalytic reduction of $\mathrm{NO}$ with $\mathrm{NH}_{3}[7,8]$, the oxidation of alcohol $[9,10]$, and the removal of hydrogen sulfide [11]. Various active manganese oxides and dispersion of particles can be obtained using different precursors and preparation methods, which seriously influence the activity of the catalysts in catalytic reactions or other utilizations.

Supercritical water (SCW, above $647 \mathrm{~K}$ and $22.1 \mathrm{MPa}$ ) can provide an excellent reaction environment for hydrothermal synthesis. The physical and chemical properties of water, such as viscosity, diffusion coefficient, dielectric constant, and ionic product, vary dramatically around the critical point depending on the state variables (pressure, temperature, and density) [12-14]. These properties make fast reaction rate and crystal nucleation rate which leads to high degree of crystallinity, small grain size, and narrow size distribution of the produce materials [15]. The size and morphology of the produced particles can be controlled by the pressure and temperature during preparation [16]. In addition, there is no liquid-gas interface and surface tension in 
the supercritical state, and a homogenous reducing or oxidizing atmosphere can be obtained by introducing oxygen, hydrogen, or other gases $[17,18]$. The supercritical hydrothermal synthesis method can also synthesize many materials that conventional hydrothermal synthesis method or solid-phase synthesis cannot synthesize. Thus, these specific properties of supercritical water have contributed to its widespread applications in materials synthesis [19-22], catalysis [23-25], and semiconductor [26, 27].

Our recent work found that the precursor of Mn plays a crucial role during the supercritical water impregnation, and $\mathrm{Mn}_{3} \mathrm{O}_{4}$ and $\mathrm{Mn}_{2} \mathrm{SiO}_{4}$ can be obtained from $\mathrm{Mn}\left(\mathrm{NO}_{3}\right)_{2}$ and $\mathrm{Mn}(\mathrm{Ac})_{2} \cdot 4 \mathrm{H}_{2} \mathrm{O}$ reacting with $\mathrm{Si}$ species containing in coalderived active carbon, respectively [28].

In this work, we proposed a supercritical water synthesis method for the production of $\mathrm{Mn}_{2} \mathrm{SiO}_{4}$ and $\mathrm{SiO}_{2}$ supported manganese oxide. A series of manganese salts $\left(\mathrm{Mn}\left(\mathrm{NO}_{3}\right)_{2}\right.$, $\mathrm{MnCl}_{2}, \mathrm{MnSO}_{4}$, and $\mathrm{Mn}(\mathrm{Ac})_{2}$ ) and silicon materials (silica sand, silica sol, and tetraethyl orthosilicate) were used as raw materials. Three kinds of products $\left(\mathrm{MnO}_{2}, \mathrm{Mn}_{2} \mathrm{O}_{3}\right.$, and $\mathrm{Mn}_{2} \mathrm{SiO}_{4}$ ) can be selectively produced by choosing different raw materials. The roles of both anions of manganese salts and silicon sources in the formation of the products under supercritical water conditions were discussed primarily.

\section{Experimental}

2.1. Materials. Manganese nitrate $\left(50 \% \mathrm{Mn}\left(\mathrm{NO}_{3}\right)_{2}\right.$ in water), manganese chloride $\left(\mathrm{MnCl}_{2}\right)$, manganese sulfate monohydrate $\left(\mathrm{MnSO}_{4} \cdot \mathrm{H}_{2} \mathrm{O}\right)$, manganese acetate tetrahydrate $\left(\mathrm{MnC}_{4} \mathrm{H}_{6} \mathrm{O}_{4} \cdot 4 \mathrm{H}_{2} \mathrm{O}\right)$, and tetraethyl orthosilicate $\left(\mathrm{C}_{8} \mathrm{H}_{20} \mathrm{O}_{4} \mathrm{Si}\right)$ were obtained from Aladdin Chemistry Co. (Shanghai, China). JN-30 silica sol, N-butanol $\left(\mathrm{C}_{4} \mathrm{H}_{10} \mathrm{O}\right)$, hydrofluoric acid, and silica sand were obtained from Fengchuan Chemistry Co. (Tianjin, China). Distilled and deionized (DDI) water was produced in our lab. The purities of all chemicals except manganese nitrate are above $98 \%$.

2.2. Apparatus. The sample synthesis was conducted using a $16.7 \mathrm{~mL}$ stainless steel tube reactor. Figure 1 shows the schematic diagram of the tube reactor system. It was heated by a molten salt bath, and the temperature of salt bath was measured by a K-type thermocouple. The molten salt bath is made of $45 \mathrm{wt} \% \mathrm{KNO}_{3}$ and $55 \mathrm{wt} \% \mathrm{NaNO}_{3}$. It helps to keep the temperature of the reaction system constant and translate heat fast and uniformly. The reactor can be driven to swing up and down by a motor at a speed of 120 cycles $\cdot \mathrm{min}^{-1}$ over a range from $613 \mathrm{~K}$ to $773 \mathrm{~K}$ with $\pm 1 \mathrm{~K}$ error in our synthesis experiments. The pressure was calculated according to the temperature and the content of water in the reactor.

\subsection{Synthesis}

2.3.1. Reaction of Manganese Salt and Silica Sand. Four metal manganese salts $\left(\mathrm{Mn}\left(\mathrm{NO}_{3}\right)_{2}, \mathrm{MnCl}_{2}, \mathrm{MnSO}_{4}\right.$, and $\left.\mathrm{Mn}(\mathrm{Ac})_{2}\right)$ were dissolved in water and the salt solutions were prepared with a concentration of $1 \mathrm{M}$. Each solution was then fed into the reactor followed by an addition of silica sand. The mole

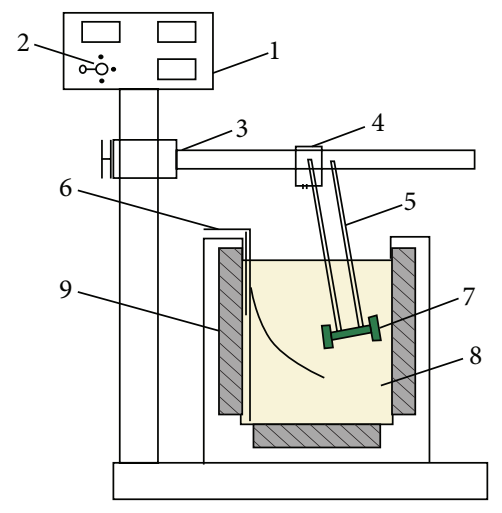

FIGURE 1: Schematic diagram of experimental apparatus. (1) temperature-controlling instrument, (2) speed controller, (3) cantilever, (4) motor, (5) crank, (6) thermocouples, (7) tube reactor, (8) $\mathrm{KNO}_{3}-\mathrm{NaNO}_{3}$ salt, and (9) heater.

ration of $\mathrm{Mn}$ : Si was kept to 1:1 The reactor was immersed into the salt bath when the desired reaction temperature was reached. After the reaction, the reactor was rapidly quenched and cooled to room temperature in a water bath. Every reaction was conducted at the temperature of $673 \mathrm{~K}$ with a resident time of 5 minutes. The content of water was $6.0 \mathrm{~mL}$ and the corresponding pressure was about as $30 \mathrm{MPa}$. The products were filtered, washed with distilled water, and dried at $343 \mathrm{~K}$ for 12 hours. The solid powders were obtained and characterized.

2.3.2. Reaction of Manganese Salt and Silica Sol. Each manganese salt solution with a concentration of $1 \mathrm{M}$ was added dropwise into the silica gel under magnetic stirring for 10 minutes. The temperature, contents of water, resistant time, and other step were the same as those in Section 2.3.1.

\subsubsection{Reaction of Manganese Salt and Tetraethyl Orthosilicate.} $10.42 \mathrm{~g}$ tetraethyl orthosilicate was mixed with $11.12 \mathrm{~g} \mathrm{n}$ butanol under magnetic stirring, in which n-butanol was used to facilitate the followed hydrolysis and condensation reaction. Then as catalyst, a mixture of $9 \mathrm{~g}$ water and $0.25 \mathrm{~g}$ HF was added dropwise into the mixture. After 25 minutes, the aqueous manganese salt solution with a concentration of $1 \mathrm{M}$ was added and then the mixture was fed into the reactor under the same conditions as those in Section 2.3.1.

2.4. Characterization. The structure of each sample was measured by X-ray diffraction (XRD) using a D/Max-2500 V/PC Rigaku X-ray diffractometer (Japan) with a $\mathrm{Cu} \mathrm{K} \alpha$ radiation source $(\lambda=0.1543 \mathrm{~nm})$ at room temperature in the range of $2 \theta=5-80^{\circ}$. The system was operated at $100 \mathrm{~mA}$ and $40 \mathrm{kV}$.

The morphology of each sample was studied using a JEOL JSM-7001F scanning electron microscope (SEM).

$\mathrm{X}$-ray photoelectron spectroscopy (XPS) was conducted to determine the surface concentration and binding energy of Mn $2 \mathrm{p}_{3 / 2}$, using a Kratos AXIS Ultra DLD spectrometer (Shimadzu, Japan) equipped with an monochromated $\mathrm{Al}$ 


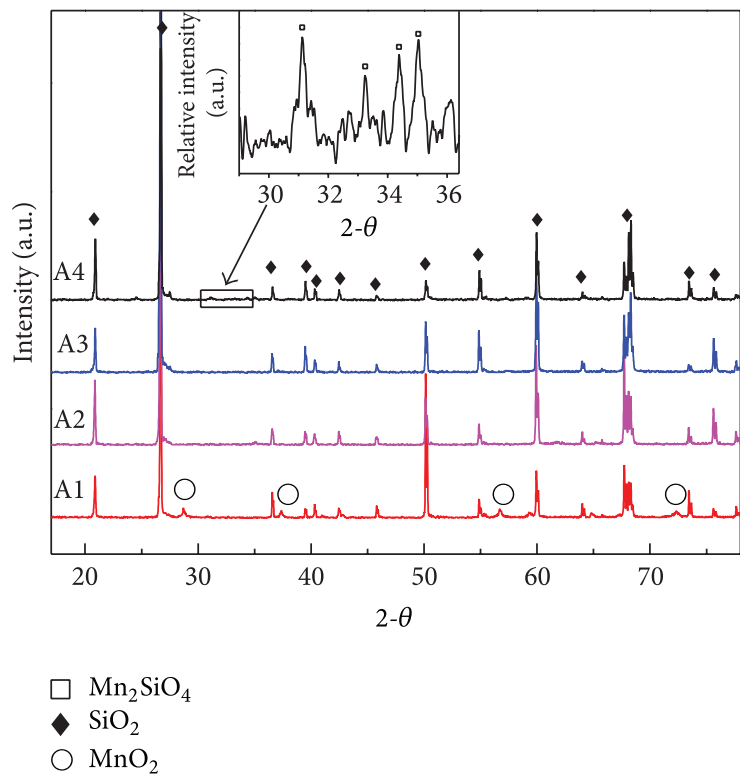

FIGURE 2: XRD patterns of samples prepared by manganese salt and silica sand (A1, A2, A3, and A4 represent the solid products from reaction of $\mathrm{Mn}\left(\mathrm{NO}_{3}\right)_{2}, \mathrm{MnCl}_{2}, \mathrm{MnSO}_{4}$, and $\mathrm{Mn}(\mathrm{Ac})_{2}$ with silica sand, resp.).

$\mathrm{K} \alpha$ source $(h v=1486.6 \mathrm{eV}, 75 \mathrm{~W})$. The spectrometer was calibrated using the photoemission lines of $\mathrm{Au}\left(\mathrm{Au} 4 \mathrm{f}_{7 / 2}=\right.$

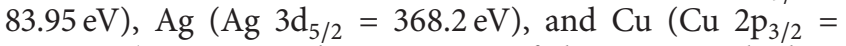
$932.62 \mathrm{eV})$. No smoothing routine of data was applied to analyze the results.

The crystalline phases of samples were measured by transmission electron microscopy (TEM) at room temperature with a JEM-2010 microscope operating at $200 \mathrm{kV}$.

\section{Results and Discussion}

3.1. XRD Characterization. XRD patterns of the samples synthesized by different manganese salts and silica sand in supercritical water are shown in Figure 2. The diffraction peaks of $\mathrm{SiO}_{2}$ crystal and $\mathrm{MnO}_{2}$ crystal can be identified in the XRD patterns of the sample (Al) prepared by $\mathrm{Mn}\left(\mathrm{NO}_{3}\right)_{2}$ and silica sand. Moreover, the intensity of $\mathrm{SiO}_{2}$ diffraction peak is much higher than that of $\mathrm{MnO}_{2}$. This means that the crystal form or the degree of crystallinity of $\mathrm{SiO}_{2}$ is far better than that of $\mathrm{MnO}_{2}$ in Al. However, all the diffraction peaks of samples (A2 and $\mathrm{A} 3$ ) synthesized by the two kinds of manganese salts $\left(\mathrm{MnCl}_{2}\right.$ and $\left.\mathrm{MnSO}_{4}\right)$ reacted with silica sand clearly show the appearance of $\mathrm{SiO}_{2}$ only. The characteristic peaks of samples (A4) obtained by the reaction of $\mathrm{Mn}(\mathrm{Ac})_{2}$ and silica sand indicate $\mathrm{Mn}_{2} \mathrm{SiO}_{4}$ and $\mathrm{SiO}_{2}$ crystal although the peak intensity of $\mathrm{Mn}_{2} \mathrm{SiO}_{4}$ (the inset in Figure 2) is very low. Based on above results, it can be concluded that $\mathrm{Mn}\left(\mathrm{NO}_{3}\right)_{2}$ and $\mathrm{Mn}(\mathrm{Ac})_{2}$ can react with silica sand in supercritical water at $673 \mathrm{~K}$ for 5 minutes and the main products are $\mathrm{MnO}_{2}$ and $\mathrm{Mn}_{2} \mathrm{SiO}_{4}$, respectively.

XRD patterns of the samples prepared by different manganese salts and silica sol in supercritical water are given

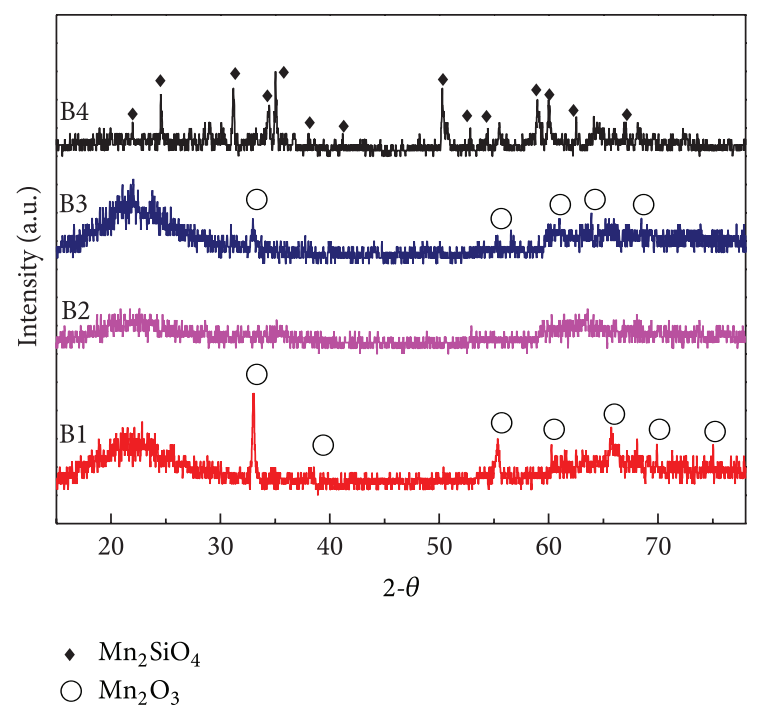

FIGURE 3: XRD patterns of samples prepared by manganese salt and silica sol. (B1, B2, B3, and B4 represent the solid products from reaction of $\mathrm{Mn}\left(\mathrm{NO}_{3}\right)_{2}, \mathrm{MnCl}_{2}, \mathrm{MnSO}_{4}$, and $\left.\mathrm{Mn}(\mathrm{Ac})_{2}\right)_{2}$ with silica sol, resp.).

in Figure 3. The diffraction peaks of $\mathrm{Mn}_{2} \mathrm{O}_{3}$ crystal can be found in the XRD patterns of the samples $\mathrm{B} 1$ and $\mathrm{B} 3$. This means that both $\mathrm{Mn}\left(\mathrm{NO}_{3}\right)_{2}$ and $\mathrm{MnSO}_{4}$ can react with silica sol to produce $\mathrm{Mn}_{2} \mathrm{O}_{3}$ at $673 \mathrm{~K}$ for 5 minutes. The broad peak at about $22^{\circ}$ can be attributed to the amorphous $\mathrm{SiO}_{2}$ hydrolyzed by the silica sol. There is no diffraction peak except the characteristic peak of the amorphous $\mathrm{SiO}_{2}$ in the XRD pattern of the sample B2. It indicates that $\mathrm{MnCl}_{2}$ cannot react with silica sol and only amorphous $\mathrm{SiO}_{2}$ can be obtained from this reaction. It is noted that the good crystalline for $\mathrm{Mn}_{2} \mathrm{SiO}_{4}$ in sample $\mathrm{B} 4$ was obtained from the reaction between $\mathrm{Mn}(\mathrm{Ac})_{2}$ and silica sol. Note that the $\mathrm{SiO}_{2}$ characteristic peaks in $\mathrm{B} 4$ cannot be resolved. The reason may be that they are marked by the peaks of the crystalline $\mathrm{Mn}_{2} \mathrm{SiO}_{4}$. It can be concluded that $\mathrm{Mn}\left(\mathrm{NO}_{3}\right)_{2}, \mathrm{MnSO}_{4}$, and $\mathrm{Mn}(\mathrm{Ac})_{2}$ can react with silica sol in supercritical water at $673 \mathrm{~K}$ for 5 minutes and the main products are $\mathrm{Mn}_{2} \mathrm{O}_{3}$ and $\mathrm{Mn}_{2} \mathrm{SiO}_{4}$.

Figure 4 shows the XRD patterns of samples prepared by different manganese salts and tetraethyl orthosilicate in supercritical water. It is found that the crystalline $\mathrm{Mn}_{2} \mathrm{SiO}_{4}$ was produced by the reaction of $\mathrm{Mn}(\mathrm{Ac})_{2}$ and tetraethyl orthosilicate $(\mathrm{Cl})$. Both $\mathrm{Mn}\left(\mathrm{NO}_{3}\right)_{2}$ and $\mathrm{MnSO}_{4}$ can react with tetraethyl orthosilicate to generate $\mathrm{Mn}_{2} \mathrm{O}_{3}$ in supercritical water. It should be noted that no characteristic peaks of $\mathrm{SiO}_{2}$, crystalline or amorphous, can be observed in the XRD pattern of Cl. It also can be found that $\mathrm{MnCl}_{2}$ could not react with tetraethyl orthosilicate in the cases of silicon sand and silica sol. Tetraethyl orthosilicate can also produce the amorphous $\mathrm{SiO}_{2}$ in supercritical water.

Based on the XRD analyses, it can be concluded that $\mathrm{Mn}(\mathrm{Ac})_{2}$ is the best manganese precursor among the four manganese salts to synthesize $\mathrm{Mn}_{2} \mathrm{SiO}_{4}$ in supercritical water. Both $\mathrm{Mn}\left(\mathrm{NO}_{3}\right)_{2}$ and $\mathrm{MnSO}_{4}$ can produce $\mathrm{Mn}_{2} \mathrm{O}_{3}$ or $\mathrm{MnO}_{2}$ 


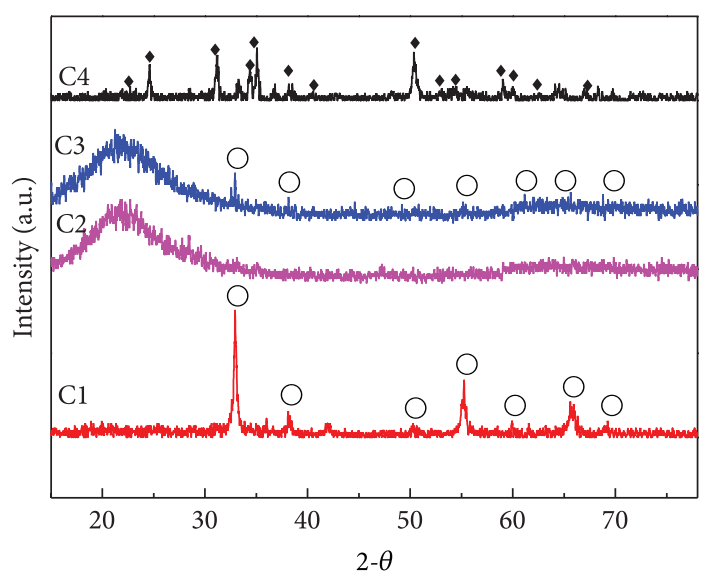

- $\mathrm{Mn}_{2} \mathrm{SiO}_{4}$

$\mathrm{Mn}_{2} \mathrm{O}_{3}$

FIGURE 4: XRD patterns of samples prepared by manganese salt and tetraethyl orthosilicate. $(\mathrm{C} 1, \mathrm{C} 2, \mathrm{C} 3$, and $\mathrm{C} 4$ represent the solid products from reaction of $\mathrm{Mn}\left(\mathrm{NO}_{3}\right)_{2}, \mathrm{MnCl}_{2}, \mathrm{MnSO}_{4}$, and $\left.\mathrm{Mn}(\mathrm{Ac})_{2}\right)_{2}$ with tetraethyl orthosilicate, resp.).

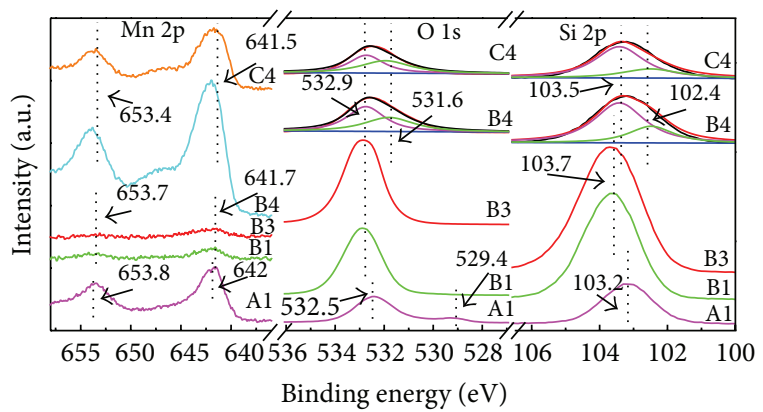

FIGURE 5: Mn 2p, O 1s, and Si 2p XPS spectra of samples prepared by reaction between different aqueous manganese salt $\left(\mathrm{Al}: \mathrm{Mn}\left(\mathrm{NO}_{3}\right)_{2}\right.$ with silica sand, $\mathrm{B}$ : $\mathrm{Mn}\left(\mathrm{NO}_{3}\right)_{2}$ with silica sol, B3: $\mathrm{MnSO}_{4}$ with silica sol, B4: $\mathrm{Mn}(\mathrm{Ac})_{2}$ with silica sol, and C4: $\mathrm{Mn}(\mathrm{Ac})_{2}$ with tetraethyl orthosilicate, resp.).

while $\mathrm{MnCl}_{2}$ could not react with any of the three kinds of silicon materials.

On the aspect of silicon source, tetraethyl orthosilicate and silica sol have similar activity and both can react with $\mathrm{Mn}(\mathrm{Ac})_{2}$ to produce $\mathrm{Mn}_{2} \mathrm{SiO}_{4}$. Silica sand has the least reactive among the three kinds of silicon sources and only $\mathrm{Mn}(\mathrm{Ac})_{2}$ can react with it to generate small amount of $\mathrm{Mn}_{2} \mathrm{SiO}_{4}$ in supercritical water. That is due to the high stability of the $\mathrm{SiO}_{2}$ crystal which is the main component of silicon sand. The diffraction peaks from $\mathrm{SiO}_{2}$ of $\mathrm{B} 4$ and $\mathrm{C} 4$ in Figures 3 and 4 may be covered by that of $\mathrm{Mn}_{2} \mathrm{SiO}_{4}$.

3.2. XPS Characterization. The chemical states of the surface species of the representative products were investigated using XPS and the results are presented in Figure 5. And the surface atomic concentrations of samples characterized by XPS results are shown in Table 1. The amounts of Mn on the surface of sample $\mathrm{A} 1$ are $6.11 \%$, while those of samples $\mathrm{B} 1$ and
TABLE 1: Surface atomic concentration (\%) of samples characterized by XPS.

\begin{tabular}{lccccc}
\hline Sample & Mn 2p & O 1s & Si 2p & N 1s & C 1s \\
\hline A1 & 6.11 & 69.62 & 23.21 & 1.06 & - \\
B1 & 0.70 & 69.66 & 29.35 & 0.35 & - \\
B3 & 0.39 & 65.82 & 27.46 & 0.26 & 6.07 \\
B4 & 7.38 & 51.30 & 15.57 & - & 25.75 \\
C4 & 2.99 & 36.46 & 4.99 & - & 55.56 \\
\hline
\end{tabular}

Note: A1, B1, B3, B4, and C4 are the samples from reaction of $\mathrm{Mn}\left(\mathrm{NO}_{3}\right)_{2}$ with silica sand, $\mathrm{Mn}\left(\mathrm{NO}_{3}\right)_{2}$ with silica sol, $\mathrm{MnSO}_{4}$ with silica sol, $\mathrm{Mn}(\mathrm{Ac})_{2}$ with silica sol, and $\mathrm{Mn}(\mathrm{Ac})_{2}$ with tetraethyl orthosilicate, respectively.

B3 are only $0.70 \%$ and $0.39 \%$, respectively. As for the Mn $2 p$ spectra, different products exhibit different binding energies (BE) of $M n 2 p_{3 / 2}$ and $M n 2 p_{1 / 2}$ levels. The binding energies of the $\mathrm{Mn} 2 \mathrm{p}_{3 / 2}$ and $\mathrm{Mn} 2 \mathrm{p}_{1 / 2}$ in the sample A1 are $642.0 \mathrm{eV}$ and $653.8 \mathrm{eV}$, which is attributed to $\mathrm{MnO}_{2}$ [28-30]. Similarly, the $\mathrm{BE}$ of the Mn $2 \mathrm{p}_{3 / 2}$ and $\mathrm{Mn} 2 \mathrm{p}_{1 / 2}$ in the samples $\mathrm{B} 1$ and $\mathrm{B} 3$ are $641.7 \mathrm{eV}$ and $653.7 \mathrm{eV}$ which can be assigned to $\mathrm{Mn}_{2} \mathrm{O}_{3}$ $[28,29]$. This also agrees well with the XRD results. Compared with the Mn 2p spectra of A1, the peak intensities belonging to $\mathrm{B} 1$ and $\mathrm{B} 3$ are very weak; this is because the surface atomic concentration of samples $\mathrm{B} 1$ and $\mathrm{B} 3$ is very low. In addition, the $\mathrm{BE}$ of the Mn $2 \mathrm{p}_{3 / 2}$ and $\mathrm{Mn} 2 \mathrm{p}_{1 / 2}$ in the sample B4 and $\mathrm{C} 4$ are in the range of $641.7-642.2 \mathrm{eV}$ and $653.4-653.7 \mathrm{eV}$, respectively. These may be attributed to $\mathrm{Mn}_{2} \mathrm{SiO}_{4} / \mathrm{MnSiO}_{3}$, $\mathrm{MnO}$, and/or their mixtures [31]. The peak intensity of $\mathrm{B} 4$ is the highest among the five lines, which is in agreement with the surface atomic concentration. The surface atomic concentration of $\mathrm{Mn}$ in sample B4 is the highest (7.38\%, Table 1).

As for the $\mathrm{O}$ 1s region, the $\mathrm{BE}$ of $\mathrm{O}$ 1s in the sample $\mathrm{A} 1$ are $532.5 \mathrm{eV}$ and $529.4 \mathrm{eV}$, which are attributed to $\mathrm{SiO}_{2}$ and $\mathrm{MnO}_{2}$, respectively $[30,32]$. The $\mathrm{BE}$ of $\mathrm{O} 1 \mathrm{~s}$ in samples $\mathrm{B} 1$ and $\mathrm{B} 3$ are $532.9 \mathrm{eV}$, which can be assigned to $\mathrm{SiO}_{2}$ [32]. However, the $\mathrm{O}$ 1s peak assigned to $\mathrm{Mn}_{2} \mathrm{O}_{3}$ in samples $\mathrm{B} 1$ and $\mathrm{B} 3$ is not resolved; it is possibly because the XPS signal of $\mathrm{Mn}_{2} \mathrm{O}_{3}$ in samples $\mathrm{B} 1$ and $\mathrm{B} 3$ is too weak comparing to $\mathrm{SiO}_{2}$. The $\mathrm{BE}$ of O 1s in samples B4 and C4 appearing at the positions of $533.9 \mathrm{eV}$ and $531.6 \mathrm{eV}$ can be attributed to $\mathrm{SiO}_{2}$ and $\mathrm{Mn}_{2} \mathrm{SiO}_{4} / \mathrm{MnSiO}_{3}$, $\mathrm{MnO}$, and/or their mixtures [31], respectively.

As for the Si $2 p$ spectra, the Si $2 p$ peak in sample A1 at $103.2 \mathrm{eV}$ is attributed to $\mathrm{SiO}_{2}$ [32] but is attributed to $\mathrm{SiO}_{2}$ in samples $\mathrm{B} 1$ and $\mathrm{B} 3$ appearing at the position of $103.7 \mathrm{eV}$, which shifted slightly higher. The $\mathrm{Si} 2 \mathrm{p}$ peaks in the samples $\mathrm{B} 4$ and $\mathrm{C} 4$ at $103.5 \mathrm{eV}$ and $102.4 \mathrm{eV}$ are attributed to $\mathrm{SiO}_{2}$ and $\mathrm{Mn}_{2} \mathrm{SiO}_{4}$ [31], respectively. Combined with the XRD results, Mn2p XPS spectra, and O1s XPS spectra, the products synthesized by $\mathrm{Mn}(\mathrm{Ac})_{2}$ and silica sol or tetraethyl orthosilicate contain $\mathrm{Mn}_{2} \mathrm{SiO}_{4}$ and $\mathrm{SiO}_{2}$.

3.3. TEM Characterization. Figure 6 shows the representative TEM images of all samples. It was revealed that fine particles with high level of dispersion were formed on the bulk products in A1 and the morphology of bulk products was single sphere. Based on the XRD analyses, the fine particles were $\mathrm{MnO}_{2}$, and the bulk products were $\mathrm{SiO}_{2}$. TEM 

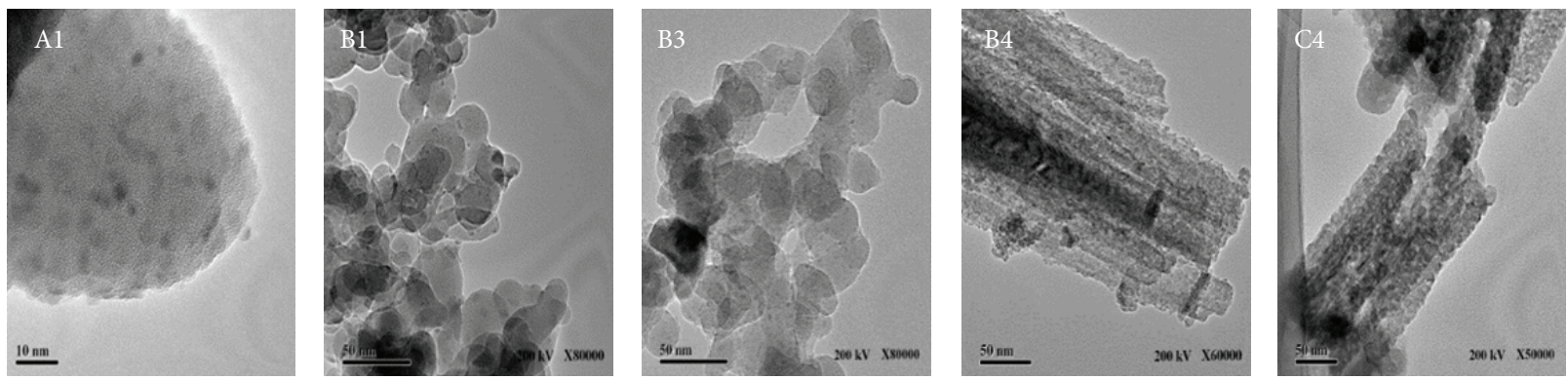

FIGURE 6: High resolution TEM images of samples prepared by reaction between different aqueous manganese salt $\left(\mathrm{Al}: \mathrm{Mn}\left(\mathrm{NO}_{3}\right)_{2}\right.$ with silica sand, B1: $\mathrm{Mn}\left(\mathrm{NO}_{3}\right)_{2}$ with silica sol, B3: $\mathrm{MnSO}_{4}$ with silica sol, $\mathrm{B} 4: \mathrm{Mn}(\mathrm{Ac})_{2}$ with silica sol, and $\mathrm{C} 4: \mathrm{Mn}(\mathrm{Ac})_{2}$ with tetraethyl orthosilicate).
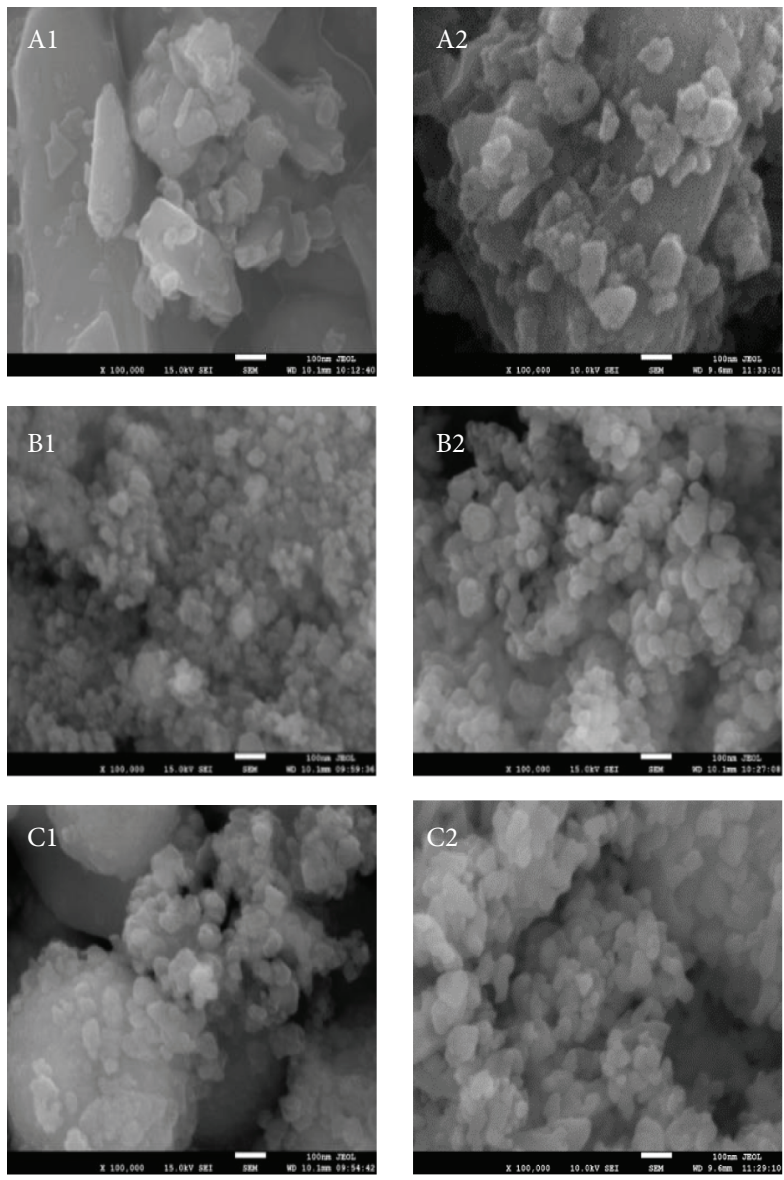
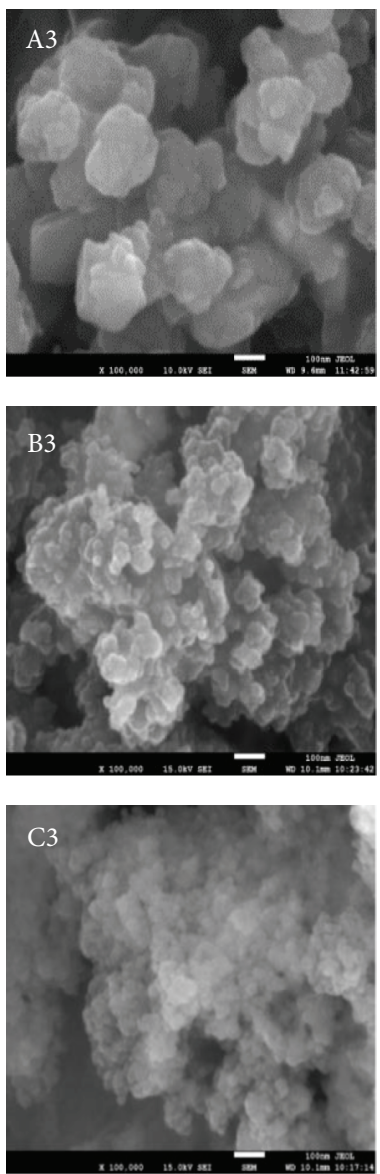
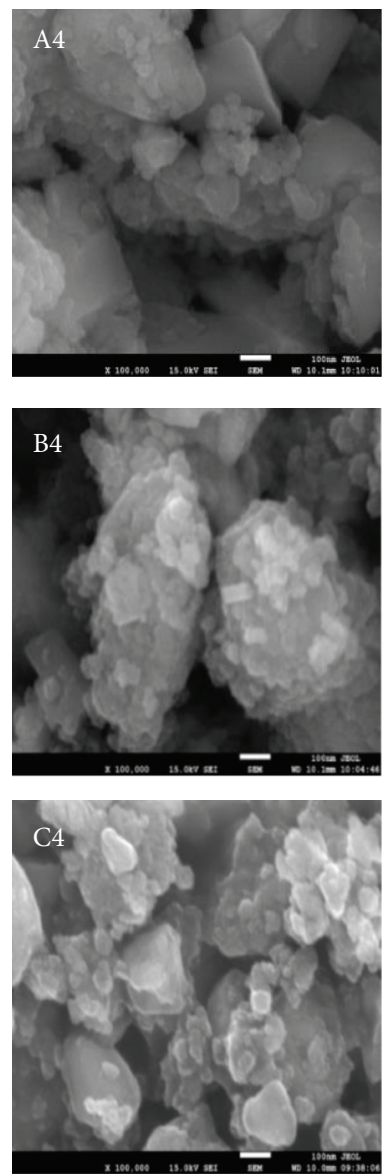

FIGURE 7: SEM images of samples prepared by reaction between various sources of silica (A: silica sand, B: silica sol, C: tetraethyl orthosilicate) and different aqueous manganese salt $\left(1: \mathrm{Mn}\left(\mathrm{NO}_{3}\right)_{2}, 2: \mathrm{MnCl}_{2}, 3: \mathrm{MnSO}_{4}\right.$, and 4: $\left.\mathrm{Mn}(\mathrm{Ac})_{2}\right)$.

images of B1 and B3 samples were similar: highly dispersed fine particles were formed on top of the bulk products, and the bulk products were uniform spheres with a diameter of approximate $20 \mathrm{~nm}$. These spheres were bonded together and formed some irregular rings with a diameter of about $40 \mathrm{~nm}$. Based on the XRD analyses, the fine particles should be $\mathrm{Mn}_{2} \mathrm{O}_{3}$, and the bulk products should be $\mathrm{SiO}_{2}$. TEM images of samples B4 and C4 were similar: stick-like products were obtained with a length of about $200 \mathrm{~nm}$. The chemical composition of products may be $\mathrm{Mn}_{2} \mathrm{SiO}_{4}$ or a mixture of $\mathrm{Mn}_{2} \mathrm{SiO}_{4}$ and $\mathrm{SiO}_{2}$.

3.4. SEM Characterization. SEM micrographs of the solid products were shown in Figure 7 . The products obtained by different manganese salts reacting with silica sand are some fine particles and irregular flaky polyhedron. While the products generated by reactions between different salts $\left(\mathrm{Mn}\left(\mathrm{NO}_{3}\right)_{2}, \mathrm{MnSO}_{4}\right.$, and $\left.\mathrm{MnCl}_{2}\right)$ and silica sol or tetraethyl 
orthosilicate are regular spheres and fine particles, the products formed by $\mathrm{Mn}(\mathrm{Ac})_{2}$ and silica sol or tetraethyl orthosilicate are slightly different, agglomerated to be unregular ellipsoid and flaky polyhedron.

3.5. Reaction Mechanism. The main products synthesized from four kinds of manganese salts and three kinds of silicon sources under supercritical water conditions are one or several of the followings: $\mathrm{SiO}_{2}, \mathrm{MnO}_{2}, \mathrm{Mn}_{2} \mathrm{O}_{3}$, and $\mathrm{Mn}_{2} \mathrm{SiO}_{4}$. And the reaction mechanism will be discussed in this section.

The $\mathrm{SiO}_{2}$ gel micronucleus can be formed by the hydrolysis and condensation reaction of tetraethyl orthosilicate. This is a fast and environmentally friendly process, and the reaction equation can be expressed as follows:

$$
\begin{array}{r}
\mathrm{Si}\left(\mathrm{OC}_{2} \mathrm{H}_{5}\right)_{4}+4 \mathrm{H}_{2} \mathrm{O} \underset{\mathrm{C}_{4} \mathrm{H}_{10} \mathrm{O}}{\stackrel{\mathrm{HF}}{\longrightarrow}} 4 \mathrm{C}_{2} \mathrm{H}_{5} \mathrm{OH}+\mathrm{Si}(\mathrm{OH})_{4} \\
\text { (Hydrolysis) } \\
n S i(\mathrm{OH})_{4} \underset{\mathrm{C}_{4} \mathrm{H}_{10} \mathrm{O}}{\stackrel{\mathrm{HF}}{\longrightarrow}} n(\equiv \mathrm{Si}-\mathrm{OH})+\mathrm{mH}_{2} \mathrm{O}
\end{array}
$$

(Condensation [39])

All the manganese salts can hydrolyze first in the water:

$$
\mathrm{MnX}_{2 / y} \rightleftharpoons \mathrm{Mn}^{2+}+2 / y \mathrm{X}^{y-} \text { (Dissociation) }
$$

$\left(\mathrm{X}\right.$ is $\mathrm{NO}_{3}{ }^{-}, \mathrm{SO}_{4}{ }^{2-}, \mathrm{Cl}^{-}$, and $\mathrm{Ac}^{-}$, and $\left.y=1,2\right)$

$$
\mathrm{Mn}^{2+}+6 \mathrm{H}_{2} \mathrm{O} \rightleftharpoons \mathrm{Mn}^{2+}\left(\mathrm{H}_{2} \mathrm{O}\right)_{6} \text { (Hydrolysis) }
$$

The reaction equilibrium biases in favor of the left under atmospheric conditions. However, under the supercritical condition, the reaction equilibrium biases in favor of the right $[33,34]$ and the radical ion under acidic conditions such as $\mathrm{NO}_{3}{ }^{-}$will be decomposed. Chlistunoff et al. $[35,36]$ investigated the decomposition of aqueous $\mathrm{HNO}_{3}$ solution in supercritical water and reported that $\mathrm{NO}_{2}$ or $\mathrm{HNO}_{2}$ and $\mathrm{O}_{2}$ can be formed at $673 \mathrm{~K}$. If a reducing agent was added, $\mathrm{NO}$ and $\mathrm{N}_{2} \mathrm{O}$ can be generated. The reaction equation of hydrothermal decomposition and oxidation can $[27,33,34]$ be expressed as follows:

$$
\begin{gathered}
(5-2 x) \mathrm{Mn}^{2+}\left(\mathrm{H}_{2} \mathrm{O}\right)_{6}+2 \mathrm{NO}_{3}^{-} \rightleftharpoons(5-2 x) \mathrm{MnO}_{2}+2 \mathrm{NO}_{x} \\
+(26-10 x) \mathrm{H}_{2} \mathrm{O}+(8-4 x) \mathrm{H}^{+}
\end{gathered}
$$

(Hydrothermal decomposition and oxidation [28, 34, 35])

The $\mathrm{Mn}\left(\mathrm{NO}_{3}\right)_{2}$ can be transformed to $\mathrm{MnO}_{2}$ or $\mathrm{Mn}_{2} \mathrm{O}_{3}$ in supercritical water, but only $\mathrm{Mn}_{2} \mathrm{O}_{3}$ can be produced from $\mathrm{MnSO}_{4}$ in supercritical water. This may be attributed to the oxidative capacity of the acid ion in the supercritical water and the effect of hydroxyl ligands generated by the silicon sources. The supercritical water is an oxidative reaction environment due to the dissolved $\mathrm{O}_{2}$ and the $\mathrm{NO}_{3}{ }^{-}$has strong oxidative capacity in the supercritical water [37]. Therefore, the $\mathrm{Mn}^{2+}$ species in the $\mathrm{Mn}\left(\mathrm{NO}_{3}\right)_{2}$ supercritical water solution can be oxidized into $\mathrm{MnO}_{2}$, and the $\mathrm{SiO}_{2}$ crystal (silica sand) existing in the supercritical water almost does not affect the reaction. The $\mathrm{SO}_{4}{ }^{2-}$ with weaker oxidative capacity is hard to be decomposed compared with $\mathrm{NO}_{3}{ }^{-}$ under acidic conditions, so the oxidized Mn species cannot be produced.

The silica sands are crystal particles and the silica sol or tetraethyl orthosilicate has irregular and porous structure. There is almost no hydroxyl groups on the surface of silica sand, but plenty on the surface of the silica hydrolyzed from silica sol or tetraethyl orthosilicate [38]. Hair [39-41] has investigated the hydroxyl groups on silica surface using infrared (IR) gravimetric adsorption at various temperatures. Their results indicated that the maximum water sorption will occur at $673 \mathrm{~K}$ where both rehydration of the surface and sorption can occur simultaneously. The hydroxyl groups on the surface of $\mathrm{SiO}_{2}$ can act as ligands. It is easy to combine with $\mathrm{Mn}^{2+}$ to form complex which enhances its reactivity. The reaction of $\mathrm{MnSO}_{4}$ with silica sol or tetraethyl orthosilicate can produce $\mathrm{Mn}_{2} \mathrm{O}_{3}$, but the $\mathrm{Mn}\left(\mathrm{NO}_{3}\right)_{2}$ with silica sol or tetraethyl orthosilicate will form $\mathrm{Mn}_{2} \mathrm{O}_{3}$ while reacting with silica sand and will form $\mathrm{MnO}_{2}$. This may be because the surface hydroxyl ligands suppress the oxidation of $\mathrm{Mn}^{2+}$. $\mathrm{Cl}^{-}$has not oxidative capacity and cannot be decomposed, so there was hardly manganese oxides produced in the supercritical water by reaction of $\mathrm{MnCl}_{2}$ with any silicon sources.

The products prepared by $\mathrm{Mn}(\mathrm{Ac})_{2}$ are obviously different from the other three $\mathrm{Mn}$ salts. The reason may be that the $\mathrm{Ac}^{-}$is a good candidate which is easy to be combined with $\mathrm{Mn}^{2+}$ via a ligand exchange reaction to form $\mathrm{Mn}^{2+}\left(\mathrm{H}_{2} \mathrm{O}\right)_{x}\left(\mathrm{Ac}^{-}\right)_{6-x}$ instead of the hydrolysis of $\mathrm{Mn}^{2+}(\mathrm{H} 2 \mathrm{O})_{6}$ to form $\mathrm{Mn}$ oxides according to

$$
\begin{aligned}
\mathrm{Mn}^{2+}\left(\mathrm{H}_{2} \mathrm{O}\right)_{6}+(6-x) \mathrm{Ac}^{-} \rightleftharpoons & \mathrm{Mn}^{2+}\left(\mathrm{H}_{2} \mathrm{O}\right)_{x}\left(\mathrm{Ac}^{-}\right)_{6-x} \\
& +(6-x) \mathrm{H}_{2} \mathrm{O}
\end{aligned}
$$

(Ligands exchange)

The $\mathrm{H}_{2} \mathrm{O}$ and $\mathrm{Ac}^{-}$ligands are further exchanged with surface hydroxyl ligands of $\mathrm{SiO}_{2}$ forming $\mathrm{Mn}_{2} \mathrm{SiO}_{4}$ and the reaction can be expressed as follows $[27,42]$ :

$$
\begin{aligned}
2 \mathrm{Mn}^{2+} & \left(\mathrm{H}_{2} \mathrm{O}\right)_{x}\left(\mathrm{Ac}^{-}\right)_{6-x}+\mathrm{HO}-\mathrm{Si} \equiv \\
& \longrightarrow \mathrm{Mn}_{2} \mathrm{SiO}_{4}+\mathrm{CO}_{2}+\mathrm{H}_{2} \mathrm{O} \quad \text { (Complexation) }
\end{aligned}
$$

By these ligands exchanging reactions, the $\mathrm{Mn}_{2} \mathrm{SiO}_{4}$ loaded on the surface of $\mathrm{SiO}_{2}$ was generated. Due to the different morphology and chemical composition of $\mathrm{SiO}_{2}$, the amount of resulting $\mathrm{Mn}_{2} \mathrm{SiO}_{4}$ varied: the silica sol and tetraethyl orthosilicate produced more $\mathrm{Mn}_{2} \mathrm{SiO}_{4}$ for more surface hydroxyl ligands and amorphous surface which is easy to interact with the reactants, while the silica sand has fewer hydroxyl ligands and regular crystal structure which leads to poor reactivity. 


\section{Conclusions}

Reactions of various manganese salts $\left(\mathrm{Mn}\left(\mathrm{NO}_{3}\right)_{2}, \mathrm{MnCl}_{2}\right.$, $\mathrm{MnSO}_{4}$, and $\mathrm{Mn}(\mathrm{Ac})_{2}$ ) and various silicon sources (silica sand, silica sol, and tetraethyl orthosilicate) have been investigated in supercritical water using a tube reactor. It is found that the anion of manganese salt has a significant effect on the composition of products. The inorganic manganese salt with the oxyacid radical, which is easy to be decomposed, can produce $\mathrm{MnO}_{2} / \mathrm{SiO}_{2}$ and $\mathrm{Mn}_{2} \mathrm{O}_{3} / \mathrm{SiO}_{2}$. The organic manganese salt with ligands like $\mathrm{Mn}(\mathrm{Ac})_{2}$ can react with various types of silicon to generate $\mathrm{Mn}_{2} \mathrm{SiO}_{4}$. The hydroxyl groups on the surface of $\mathrm{SiO}_{2}$ from different silicon sources enhance the reactivity of $\mathrm{SiO}_{2}$. Depending on the applications, the selective materials can be fast synthesized in supercritical water by choosing different Mn salt precursor and different types of silicon sources.

\section{Conflict of Interests}

The authors declare that there is no conflict of interests regarding the publication of this paper.

\section{Acknowledgments}

The financial support from the National Natural Science Foundation of China (20976117) and China Postdoctoral Science Foundation (CPSF, 20110491630) is gratefully acknowledged.

\section{References}

[1] P. Casey, J. Bogan, J. G. Lozano, P. D. Nellist, and G. Hughes, "Chemical and structural investigation of the role of both $\mathrm{Mn}$ and $\mathrm{Mn}$ oxide in the formation of manganese silicate barrier layers on $\mathrm{SiO}_{2}$," Journal of Applied Physics, vol. 110, no. 5, Article ID 054507, 2011.

[2] V. K. Dixit, K. Neishi, N. Akao, and J. Koike, "Structural and electronic properties of a $\mathrm{Mn}$ oxide diffusion barrier layer formed by chemical vapor deposition," IEEE Transactions on Device and Materials Reliability, vol. 11, no. 2, pp. 295-302, 2011.

[3] Y. Otsuka, J. Koike, H. Sako et al., "Graded composition and valence states in self-forming barrier layers at $\mathrm{Cu}-\mathrm{Mn} / \mathrm{SiO}_{2}$ interface," Applied Physics Letters, vol. 96, no. 1, Article ID 012101, 2010.

[4] P. Casey, J. Bogan, B. Brennan, and G. Hughes, "Synchrotron radiation photoemission study of in situ manganese silicate formation on $\mathrm{SiO}_{2}$ for barrier layer applications," Applied Physics Letters, vol. 98, no. 11, Article ID 113508, 2011.

[5] J. Iijima, Y. Fujii, K. Neishi, and J. Koike, "Resistivity reduction by external oxidation of $\mathrm{Cu}-\mathrm{Mn}$ alloy films for semiconductor interconnect application," Journal of Vacuum Science and Technology B: Microelectronics and Nanometer Structures, vol. 27, no. 4, pp. 1963-1968, 2009.

[6] J. M. Ablett, J. C. Woicik, Z. Tökei, S. List, and E. Dimasi, "Phase identification of self-forming $\mathrm{Cu}-\mathrm{Mn}$ based diffusion barriers on p-SiOC:H and $\mathrm{SiO}_{2}$ dielectrics using x-ray absorption fine structure," Applied Physics Letters, vol. 94, no. 4, Article ID 042112, 2009.
[7] S. M. Soltani, S. Hosseini, and M. R. Malekbala, "A review on monolithic honeycomb structures and fabrication techniques," Applied Scientific Research, vol. 9, no. 4, pp. 1-12, 2013.

[8] E. García-Bordejé, M. J. Lázaro, R. Moliner, J. F. Galindo, J. Sotres, and A. M. Baró, "Structure of vanadium oxide supported on mesoporous carbon-coated monoliths and relationship with its catalytic performance in the SCR of NO at low temperatures," Journal of Catalysis, vol. 223, no. 2, pp. 395-403, 2004.

[9] V. R. Choudhary, P. A. Chaudhari, and V. S. Narkhede, "Solventfree liquid phase oxidation of benzyl alcohol to benzaldehyde by molecular oxygen using non-noble transition metal containing hydrotalcite-like solid catalysts," Catalysis Communications, vol. 4, no. 4, pp. 171-175, 2003.

[10] Y. Su, L. C. Wang, Y. M. Liu, Y. Cao, H. Y. He, and K. N. Fan, "Microwave-accelerated solvent-free aerobic oxidation of benzyl alcohol over efficient and reusable manganese oxides," Catalysis Communications, vol. 8, no. 12, pp. 2181-2185, 2007.

[11] J. P. Wakker, A. W. Gerritsen, and J. A. Moulijn, "High temperature $\mathrm{H}_{2} \mathrm{~S}$ and $\mathrm{COS}$ removal with $\mathrm{MnO}$ and $\mathrm{FeO}$ on $\gamma-\mathrm{Al}_{2} \mathrm{O}_{3}$ acceptors," Industrial and Engineering Chemistry Research, vol. 32, no. 1, pp. 139-149, 1993.

[12] J. Fages, C. Aymonier, F. Cansell, and J. Mercadier, "New trends in supercritical fluids: energy; materials; processing. A special issue -9th international symposium on supercritical fluids, May 18-20, 2009, Arcachon, France," Journal of Supercritical Fluids, vol. 53, no. 1-3, p. 1, 2010.

[13] C. Slostowski, S. Marre, O. Babot, T. Toupance, and C. Aymonier, "Near- and supercritical alcohols as solvents and surface modifiers for the continuous synthesis of cerium oxide nanoparticles," Langmuir, vol. 28, no. 48, pp. 16656-16663, 2012.

[14] T. Glasnov, "Highlights from the flow chemistry literature 2011 (part 3)," Journal of Flow Chemistry, vol. 2, no. 1, pp. 28-36, 2012.

[15] A. Loppinet-Serani, C. Aymonier, and F. Cansell, "Supercritical water for environmental technologies," Journal of Chemical Technology and Biotechnology, vol. 85, no. 5, pp. 583-589, 2010.

[16] H. Hayashi and Y. Hakuta, "Hydrothermal synthesis of metal oxide nanoparticles in supercritical water," Materials, vol. 3, no. 7, pp. 3794-3817, 2010.

[17] F. Cansell, C. Aymonier, and A. Loppinet-Serani, "Review on materials science and supercritical fluids," Current Opinion in Solid State and Materials Science, vol. 7, no. 4-5, pp. 331-340, 2003.

[18] A. G. Kalinichev, Y. E. Gorbaty, and A. V. Okhulkov, "Structure and hydrogen bonding of liquid water at high hydrostatic pressures: Monte Carlo NPT-ensemble simulations up to 10 kbar," Journal of Molecular Liquids, vol. 82, no. 1-2, pp. 57-72, 1999.

[19] J. W. Lee, J. H. Lee, T. T. Viet, J. Y. Lee, J. S. Kim, and C. H. Lee, "Synthesis of $\mathrm{LiNi}_{1 / 3} \mathrm{Co}_{1 / 3} \mathrm{Mn}_{1 / 3} \mathrm{O}_{2}$ cathode materials by using a supercritical water method in a batch reactor," Electrochimica Acta, vol. 55, no. 8, pp. 3015-3021, 2010.

[20] Y. H. Shin, S. M. Koo, D. S. Kim et al., "Continuous hydrothermal synthesis of $\mathrm{HT}-\mathrm{LiCoO}_{2}$ in supercritical water," Journal of Supercritical Fluids, vol. 50, no. 3, pp. 250-256, 2009.

[21] K. Kanamura, A. Goto, R. Y. Ho et al., "Preparation and electrochemical characterization of $\mathrm{LiCoO}_{2}$ particles prepared by supercritical water synthesis," Electrochemical and Solid-State Letters, vol. 3, no. 6, pp. 256-258, 2000.

[22] S. A. Hong, S. J. Kim, J. Kim, K. Y. Chung, B. W. Cho, and J. W. Kang, "Small capacity decay of lithium iron phosphate $\left(\mathrm{LiFePO}{ }_{4}\right)$ synthesized continuously in supercritical water: 
comparison with solid-state method," Journal of Supercritical Fluids, vol. 55, no. 3, pp. 1027-1037, 2011.

[23] C. Xu and A. S. Teja, "Supercritical water synthesis and deposition of iron oxide $\left(\alpha-\mathrm{Fe}_{2} \mathrm{O}_{3}\right)$ nanoparticles in activated carbon," Journal of Supercritical Fluids, vol. 39, no. 1, pp. 135-141, 2006.

[24] J. R. Kim, W. Myeong, and S. K. Ihm, "Characteristics of $\mathrm{CeO}_{2}-\mathrm{ZrO}_{2}$ mixed oxide prepared by continuous hydrothermal synthesis in supercritical water as support of Rh catalyst for catalytic reduction of NO by CO," Journal of Catalysis, vol. 263, no. 1, pp. 123-133, 2009.

[25] H. Hayashi, Y. Hakuta, and Y. Kurata, "Hydrothermal synthesis of potassium niobate photocatalysts under subcritical and supercritical water conditions," Journal of Materials Chemistry, vol. 14, no. 13, pp. 2046-2051, 2004.

[26] J. D. Holmes, D. M. Lyons, and K. J. Ziegler, "Supercritical fluid synthesis of metal and semiconductor nanomaterials," Chemistry, vol. 9, no. 10, pp. 2144-2150, 2003.

[27] K. J. Ziegler, R. C. Doty, K. P. Johnston, and B. A. Korgel, "Synthesis of organic monolayer-stabilized copper nanocrystals in supercritical water," Journal of the American Chemical Society, vol. 123, no. 32, pp. 7797-7803, 2001.

[28] J. C. Wang, B. Qiu, L. N. Han et al., "Effect of precursor and preparation method on manganese based activated carbon sorbents for removing $\mathrm{H}_{2} \mathrm{~S}$ from hot coal gas," Journal of Hazardous Materials, vol. 213-214, pp. 184-192, 2012.

[29] M. Toupin, T. Brousse, and D. Bélanger, "Charge storage mechanism of $\mathrm{MnO}_{2}$ electrode used in aqueous electrochemical capacitor," Chemistry of Materials, vol. 16, no. 16, pp. 3184-3190, 2004.

[30] X. Vanden Eynde, J. P. Servais, and M. Lamberigts, "Investigation into the surface selective oxidation of dual-phase steels by XPS, SAM and SIMS," Surface and Interface Analysis, vol. 35, no. 12, pp. 1004-1014, 2003.

[31] S. Swaminathan and M. Spiegel, “Thermodynamic and kinetic aspects on the selective surface oxidation of binary, ternary and quarternary model alloys," Applied Surface Science, vol. 253, no. 10, pp. 4607-4619, 2007.

[32] V. P. Zakaznova-Herzog, H. W. Nesbitt, G. M. Bancroft, and J. S. Tse, "Characterization of leached layers on olivine and pyroxenes using high-resolution XPS and density functional calculations," Geochimica et Cosmochimica Acta, vol. 72, no. 1, pp. 69-86, 2008.

[33] T. Adschiri, Y. Hakuta, and K. Arai, "Hydrothermal synthesis of metal oxide fine particles at supercritical conditions," Industrial and Engineering Chemistry Research, vol. 39, no. 12, pp. 49014907, 2000.

[34] T. Adschiri, K. Kanazawa, and K. Arai, "Rapid and continuous hydrothermal crystallization of metal oxide particles in supercritical water," Journal of American Ceramic Society, vol. 75, no. 4, pp. 1019-1022, 1992.

[35] J. Chlistunoff, K. J. Ziegler, L. Lasdon, and K. P. Johnston, "Nitric/nitrous acid equilibria in supercritical water," Journal of Physical Chemistry A, vol. 103, no. 11, pp. 1678-1688, 1999.

[36] C. Ratcliffe and D. Irish, "Vibrational spectral studies of solutions at elevated temperatures and pressures. VII. Raman spectra and dissociation of nitric acid," Canadian Journal of Chemistry, vol. 63, no. 12, pp. 3521-3525, 1985.

[37] C. Aymonier, P. Beslin, C. Jolivalt, and F. Cansell, "Hydrothermal oxidation of a nitrogen-containing compound: the fenuron," Journal of Supercritical Fluids, vol. 17, no. 1, pp. 45-54, 2000.
[38] L. L. Hench and J. K. West, "The Sol-Gel process," Chemical Reviews, vol. 90, no. 1, pp. 33-72, 1990.

[39] M. L. Hair, "Hydroxyl groups on silica surface," Journal of NonCrystalline Solids, vol. 19, pp. 299-309, 1975.

[40] P. Van Der Voort, I. Gillis-D'Hamers, and E. F. Vansant, "Estimation of the distribution of surface hydroxyl groups on silica gel, using chemical modification with trichlorosilane," Journal of the Chemical Society, Faraday Transactions, vol. 86, no. 22, pp. 3751-3755, 1990.

[41] G. M. S. El Shafei and M. M. Mokhtar, "Interaction between molybdena and silica: FT-IR/PA studies of surface hydroxyl groups and pore structure assessment," Colloids and Surfaces A: Physicochemical and Engineering Aspects, vol. 94, no. 2-3, pp. 267-277, 1995.

[42] P. Kanninen, C. Johans, J. Merta, and K. Kontturi, "Influence of ligand structure on the stability and oxidation of copper nanoparticles," Journal of Colloid and Interface Science, vol. 318, no. 1, pp. 88-95, 2008. 

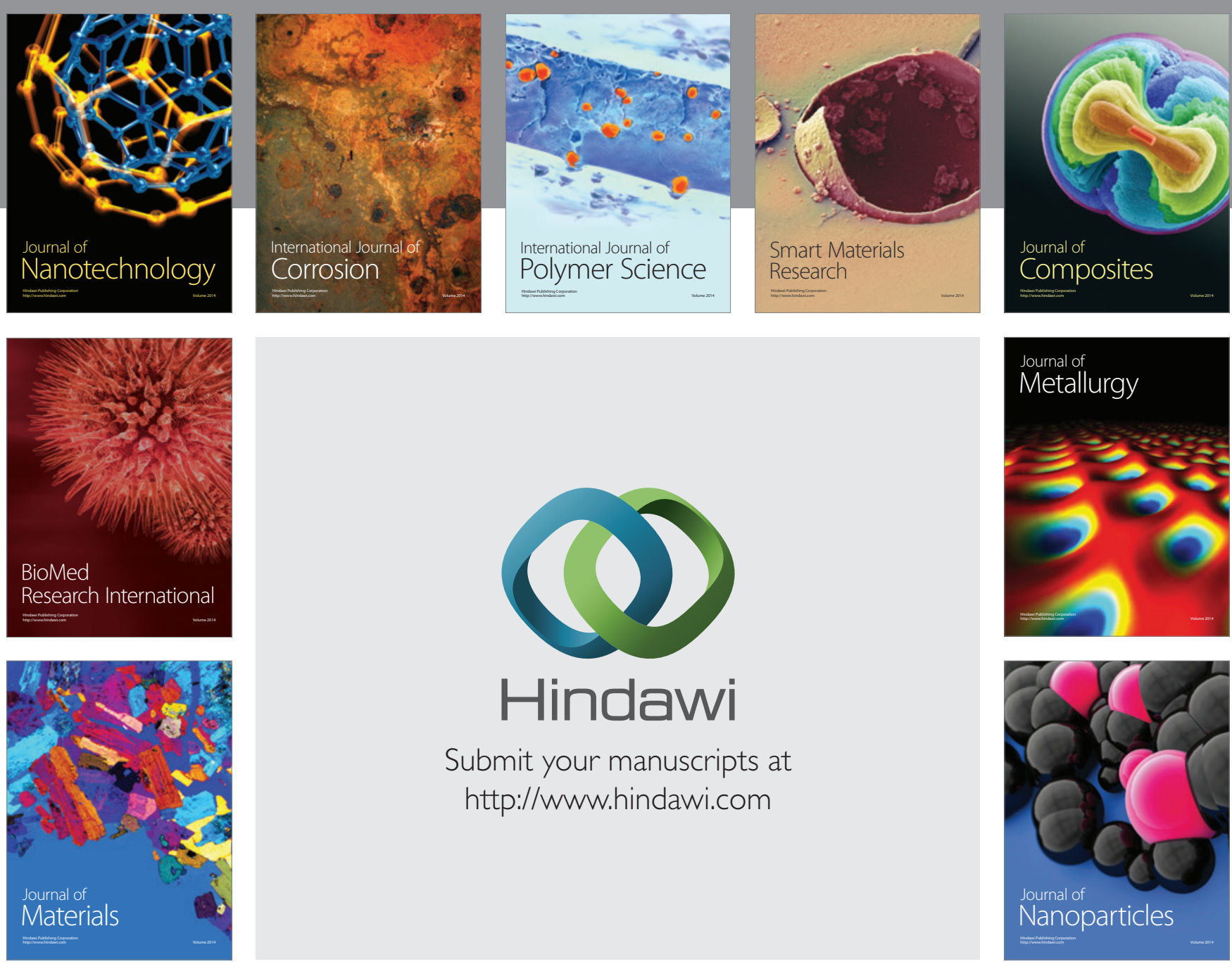

Submit your manuscripts at http://www.hindawi.com
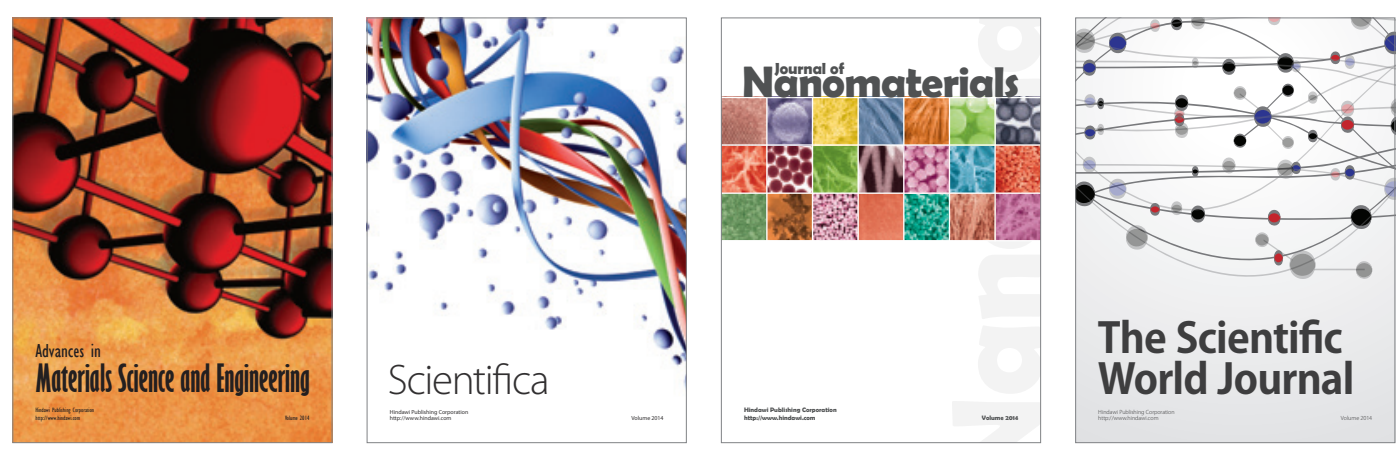

\section{The Scientific World Journal}
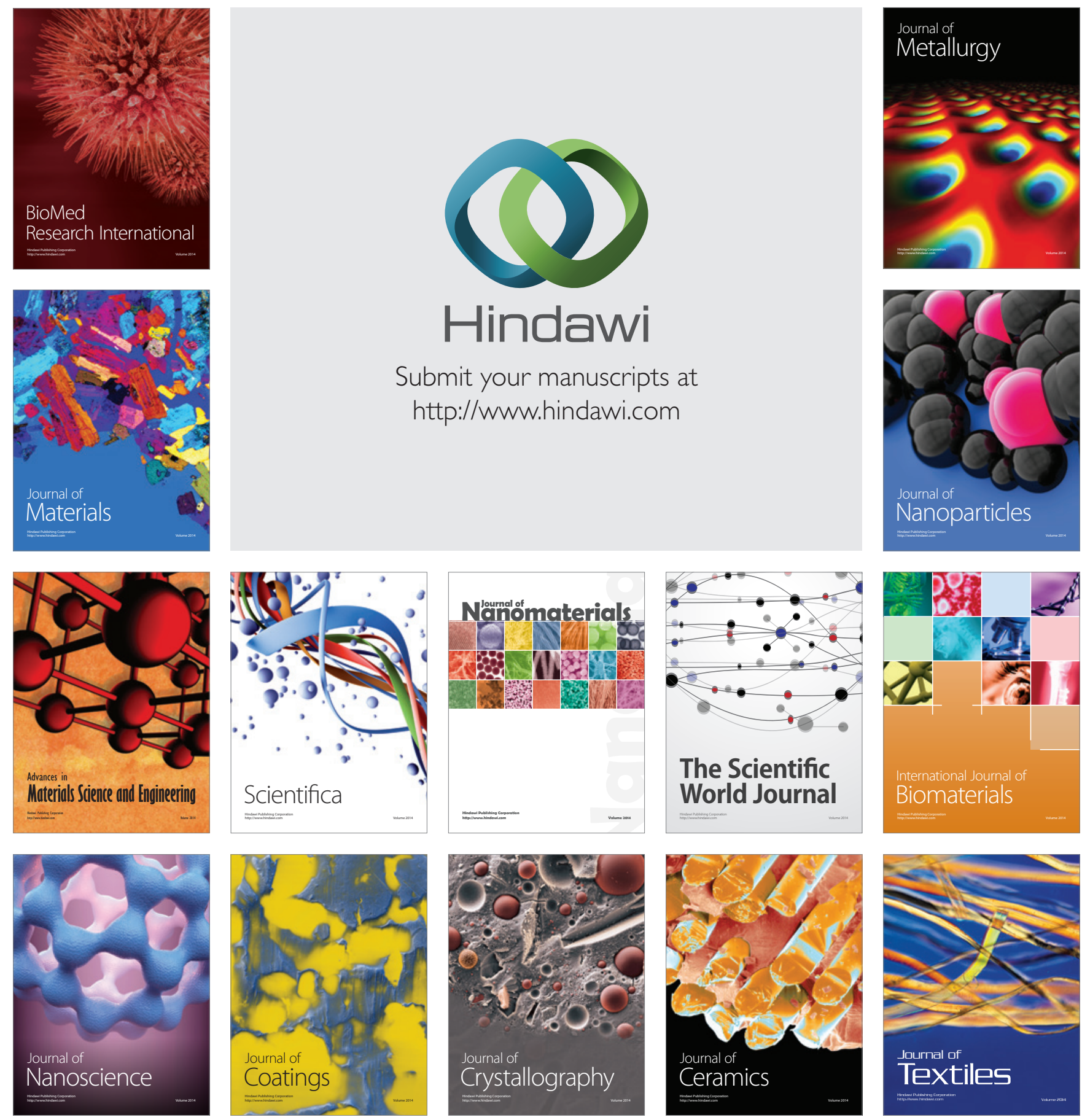